\title{
Pathogenicity of Meloidogyne incognita and Pratylenchus zeae, and Their Association with Pythium graminicola on Roots of Sugarcane in Puerto Rico ${ }^{1,2}$
}

\author{
Santos Valle-Lamboy and Alejandro Ayala
}

\begin{abstract}
Both Meloidogyne incognita and Pratylenchus zeae, acting separately, reduced significantly the height of the primary shoots, fresh and dry weight of shoots and leaves, and fresh weight of roots of sugarcane cultivar PR 980. The combined action of both nematode species also caused a significant reduction of the height of the primary shoots, weight of shoots and dry weight of leaves, but the reduction was less than that produced in plants inoculated with only one species alone. Also, when both species of nematodes were present simultaneously, the number of internodes was significantly reduced, as compared to the control, but there was no difference in the reduction caused by both species when they were applied together or each one alone. Pythium graminicola reduced significantly the height of primary shoots. The combination of each nematode species with the fungus produced a highly significant reduction of the height of the primary shoots. The reduction was lower than that produced by each nematode species acting separately, but higher than that induced by the fungus alone. No significant reduction was caused by the three microorganisms acting in combination.

The data suggested a possible acute antagonism among the two nematode species and the fungus. It also indicated that $M$. incognita, $P$. zeae and $P$. graminicola are pathogenic to sugarcane.
\end{abstract}

\section{INTRODUCTION}

Twenty-five years ago, the sugar industry was the most important source of agricultural income in Puerto Rico, but yields have decreased rapidly and recently production reached the lowest levels in many years (1). In a survey conducted by Liu et al. (10), in 1969-70 in 10 sugarcane producing areas of the Island, root rot was one of the most important diseases encountered. This condition is presumably caused by a complex of interacting pathogens, including Pythium, Fusarium and certain species of nematodes. This destructive disease reduces germination of the cultivars POJ 2878 and $\mathrm{H} 328560$ as much as $40 \%$ in poorly-drained soils.

Wellman (16) points out that studies by Rands and Dopp (12) in Barbados and in southern Louisiana conclusively proved that the fungus Pythium arrhenomanes Drechsler is the causal agent of the root rot disease. However, recent investigations $(7,13,14,17)$ have demonstrated

${ }^{1}$ Manuscript submitted to Editorial Board October 15, 1979.

${ }^{2}$ This paper was adapted from a thesis submitted by the senior author to the Faculty of the Graduate School, Mayagüez Campus, University of Puerto Rico in partial fulfillment of the requirements for the degree of Master of Science in Agronomy (1973).

${ }^{3}$ Assistant Agronomist and Nematologist, respectively, Agricultural Experiment Station, Mayagüez Campus, University of Puerto Rico, Río Piedras, P.R. 
that a great number of nematode species are associated with sugarcane roots, and that they may be responsible for the low yields prevailing in Puerto Rico and other cane producing countries.

Research $(2-4,7,13)$ has demonstrated that nematodes attack sugarcane roots, extract their cellular contents and inoculate hormones, enzymes and toxins that destroy the tissues almost completely and force the plant to produce new roots.

In Puerto Rico the fungus Pythium graminicola Subr. has been found in association with nematodes apparently aggravating the damage to the root system caused by nematodes and vice versa (9). Apt and Koike (4) demonstrated in greenhouse experiments in Hawaii, that there is an interaction between Meloidogyne incognita (Kofoid and White, 1919) Chitwood, 1949 and $P$. graminicola in relation to top growth, but not to root growth. The same authors (2) demonstrated that there is a greater reduction of the dry weight of plants grown in the presence of Helicotylenchus dihystera $(=H$. mannus) Steiner, 1945 , and $P$. graminicola than when any one of these organisms is present alone. The authors claim that the effect is apparently additive and that the results can be interpreted as proof that $H$. dihystera is both parasitic and pathogenic on sugarcane. Koike and Román (9) demonstrated in greenhouse experiments that Pratylenchus brachyurus (Godfrey, 1929) Filipjev \& Stekhoven, 1941, reduces significantly the top growth of sugarcane plants and that $P$. graminicola reduces significantly root growth. They also found that the combined effect of these pathogens corresponds to that produced by the fungus alone and concluded that the fungus apparently interferes with the pathogenic effect of the nematode.

The damage produced by nematodes is partially known, but the role of $P$. graminicola is not yet well understood. The purpose of this study was to elucidate the role that each of the biologic agents plays in the etiology of sugarcane root rot. The information gathered may serve as the base for the development of control means.

\section{MATERIALS AND METHODS}

Roots from plants of sugarcane cultivar PR 980 grown in the greenhouse were inoculated with $M$. incognita, $P$. zeae Graham 1951, and $P$. graminicola, separately and in combinations. The test included the following treatments: $M$. incognita; $P$. zeae; $P$. graminicola $M$. incognita and $P$. zeae (added simultaneously); $M$. incognita and $P$. graminicola (the latter added three weeks after the nematodes); $P$. zeae and $P$. graminicola (the latter added three weeks after the nematode); $M$. incognita, $P$. zeae and $P$. graminicola (the latter added three weeks after the nematodes); and an uninoculated control. The inocula for each treatment consisted of 1,600 larvae of $M$. incognita, 1,200 P. zeae and 
mycelia from a 6-day-old culture of $P$. graminicola. Treatments were replicated five times in a complete block design.

The experiment was harvested 60 days after planting. Determined and statistically analyzed were height of primary shoots; circumference of primary shoots three inches above soil level; number of internodes; fresh and dry weight of shoots, leaves, and roots; number of tillers; indexes of necrosis; number of galls, and nematode populations.

One-bud cuttings from apparently disease-free sugarcane stalks grown at the Lajas Substation were used. Cuttings were washed in running tap water, immersed for $5 \mathrm{~min}$ in a $2 \%$ calcium hypochlorite solution and rinsed in distilled water. The seed pieces were germinated in disinfested metal trays containing a methyl bromide-fumigated soil mixture consisting of two parts of San Antón soil to one part of cachaza (screened sugarmill filter press cake). After germination, cuttings were transferred to 8-inch clay pots containing methyl bromide-fumigated Coto soil.

The nematodes used to initiate pure cultures of $P$. zeae were obtained from infected sugarcane roots in a Coto clay at Isabela. Nematodes were extracted from roots by the incubation method (15). They were then washed in distilled water and cultured in roots of cane plants growing in a sterilized soil mixture. The nematode cultures were used 4 mo later for the inoculations.

Pure cultures of $M$. incognita were obtained from soil and roots from a sugarcane field at Aguadilla. The Baermann-funnel and the root-incubation methods (15) were used for extracting larvae from soil and roots, respectively. The recovered larvae were then washed with distilled water and cultured in roots of tomato plants grown in fumigated soil. The cultures were used as a source of inoculum 50 to 60 days later.

Nematodes were extracted from pure cultures by the above-mentioned methods. Meloidogyne incognita larvae extracted from tomato roots with the blender (15) were washed in distilled water several times before being used for inoculation.

Populations were calculated by counting the nematodes present in five samples of $0.1 \mathrm{ml}$ from the original concentration. Inoculations were then made by opening two small holes in the soil around roots and placing in them the needed amount of nematode suspension.

Pure cultures of $P$. graminicola were used from locally available stock. The fungus was kept in potato-dextrose agar (PDA) at $20^{\circ} \mathrm{C}$, and transferred every 96 hours. Inoculations were made from cultures maintained at $28^{\circ} \mathrm{C}$ for 72 hours.

The inoculum was prepared by blending for $5 \mathrm{~s}$ the contents of a 6-dayold culture of the fungus in $150 \mathrm{ml}$ of distilled water. The soil surface adjacent to the roots was slightly disturbed and the fungal suspension applied. 
At the end of each trial, nematodes were extracted from $100 \mathrm{~cm}^{3}$ soil samples by means of a combination of the Cobbs and Baermann's methods (15). Nematode extractions from roots were made by chopping $5 \mathrm{~g}$ of clean roots selected at random from the whole system into a Baermann funnel. Nematode counts were performed $24 \mathrm{~h}$ later.

During the experiment, the average minimum and maximum temperatures registered in the greenhouse at 8:00 a.m. and 12:00 m. were $23.5^{\circ}$ $\mathrm{C}$ and $34^{\circ} \mathrm{C}$, respectively.

\section{RESULTS}

The plants inoculated with either of the nematode species remained small. The control plants grew and developed more vigorously than plants in any of the other treatments, except those receiving the three pathogens together (fig. 1).

Meloidogyne incognita prevented normal development of the root system, which was comprised mainly of primary roots with small galls (fig. 2). Pratylenchus zeae caused almost total root deterioration (fig. 3). In the presence of $P$. graminicola, $M$. incognita produced nearly twice as many galls as those induced when the nematode was alone. The root systems of the control plants developed normally.

Both $M$. incognita and $P$. zeae reduced significantly the growth, shoot weight, dry weight of the leaves and the fresh weight of the leaves and roots (table 1) when compared with the controls. Meloidogyne incognita also caused a reduction of primary shoot height and dry weight of roots while $P$. zeae reduced significantly only the height of primary shoots.

The two nematode species acting together reduced top growth, number of internodes, weight of shoots and dry weight of leaves. The combination of $M$. incognita and $P$. graminicola and of $P$. zeae and $P$. graminicola reduced significantly the height of the primary shoots.

\section{DISCUSSION}

The results obtained indicate that Meloidogyne incognita and Pratylenchus zeae are pathogenic to the sugarcane cultivar PR 980; they cause a significant reduction of top growth, fresh weight of shoots and dry and fresh weight of leaves and fresh weight of roots. Similar results were obtained by Apt and Koike (4) in Hawaii, Román (13) in Puerto Rico and Winchester (17) in Florida with M. incognita. Kahn (8), in Louisiana, reported similar results with $P$. zeae. When the two nematode species are together, the fresh weight of leaves and shoots is not reduced, as when they act independently. Apparently, some sort of antagonism exists between the two species of nematodes such that the individual effect of each is altered by the presence of the other.

Pythium graminicola reduces significantly the height of primary 


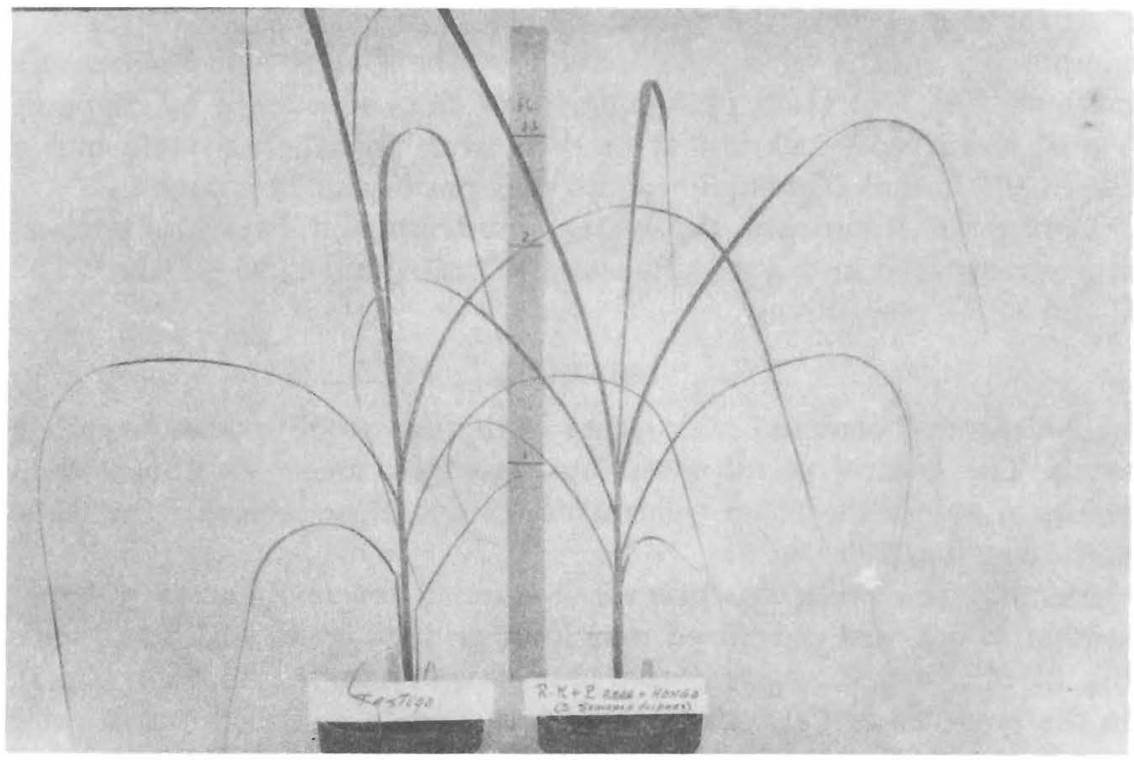

FiG. 1.-Sugarcane plant (left) of the cultivar PR 980 grown in soil free from nematodes and fungi compared to a plant (right) inoculated with 1,600 Meloidogyne incognita, 1,2000 Pratylenchus zeae and Pythium graminicola ( 3 weeks after inoculating with the nematodes).

shoots. This corroborates the observations of Apt and Koike $(2,4)$ and Koike and Román (9) in relation to its pathogenicity on sugarcane. On the other hand, when $M$. incognita acts in combination with the fungus the reduction is still significant as compared to the control but its value does not take place significantly over that caused by $M$. incognita alone. Apparently, there is an antagonistic action involved by which the presence of the nematode creates an unfavorable environment for the fungus, and in turn the fungus partially reduces the detrimental effects of the nematode. Evidently the plant benefits physiologically from this antagonistic action. The enzymes responsible for cellular dissolution, the toxins and other metabolites produced by $M$. incognita (15) during giant cell formation, and the utilization of cellular nutrients may affect $P$. gramin$i c o l a$, thus retarding or interfering with its physiological functions in galled tissue, and decreasing the available area of fungal development. Barton (5) found that Pythium mamillatum actively colonized virgin substrates rich in sugars and simple carbon compounds, but colonization is reduced if the substrate has been precolonized, because of the sensitivity of the fungus to the accumulation of metabolites. $P$. graminicola may behave similarly in cane tissue already colonized by $M$. incognita. On the other hand, even if the fungus invades slowly the tissue adjacent to the 


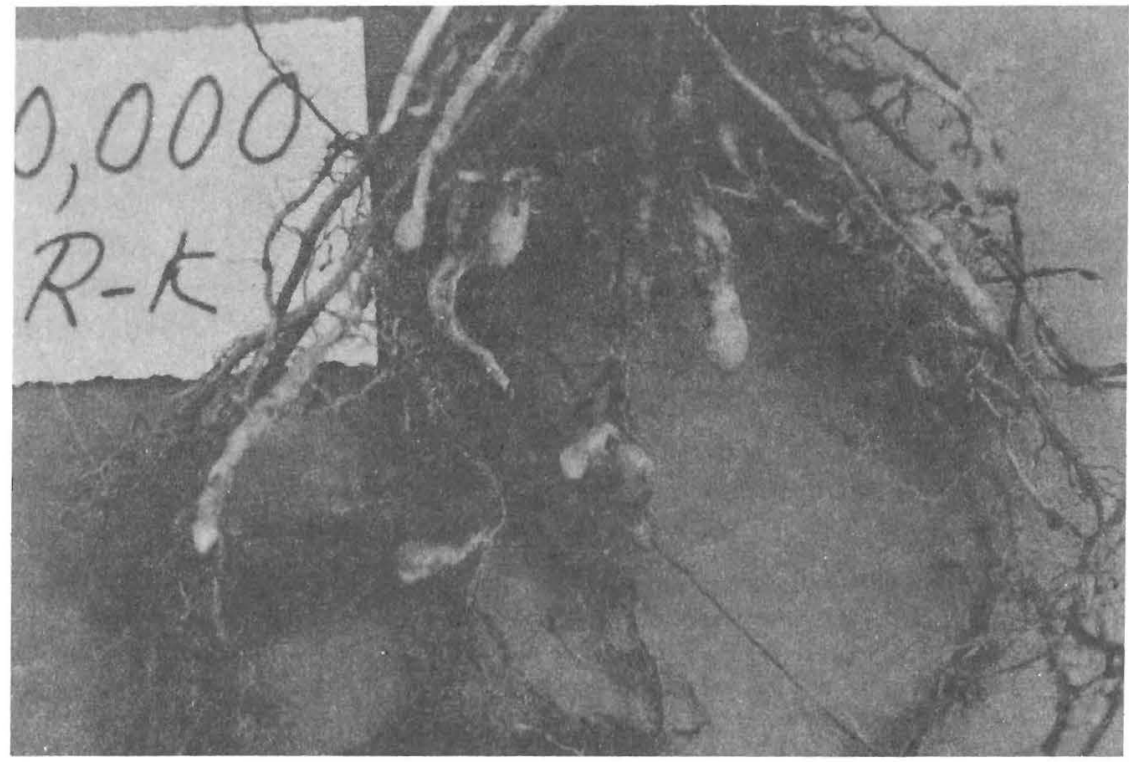

FIG. 2.-Roots of a sugarcane plant of the cultivar PR 980 with galls produced by Meloido syne incognita.

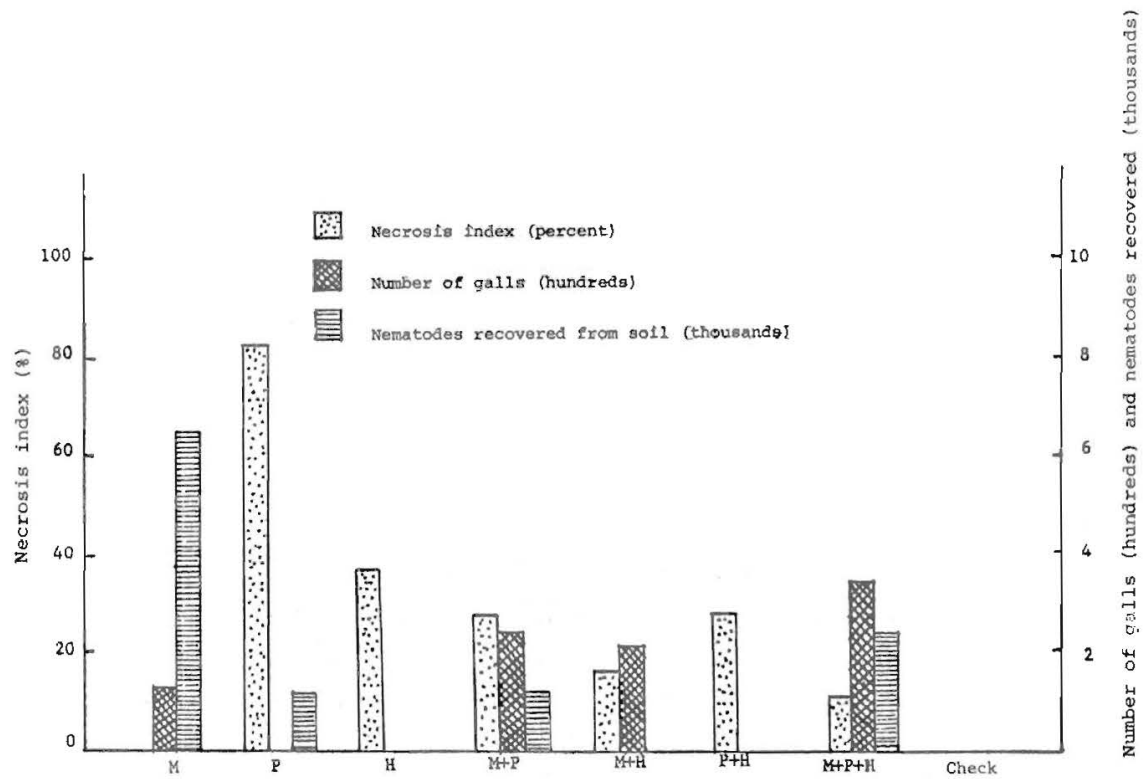

Fig. 3.-Extent of necrosis and number of galls in the roots of the sugarcane cultivar PR 980 , and nematode populations recovered from soil in relation to nematode-fungus combinations. $\mathrm{M}-$ Meloidogyne incognita; $\mathrm{P}-$ Pratylenchus zeae; $\mathrm{H}-$ Pythium graminicola. 
TABLE 1.-Effect of Meloidogyne incognita, Pratylenchus zeae and Pythium graminicola (acting separately and in combination) on the height, circumference and number of internodes of primary shoots; and on fresh and dry weight of shoots, leaves and roots of sugarcane cultivar $P R 980$

\begin{tabular}{|c|c|c|c|c|c|c|c|c|c|}
\hline \multirow{2}{*}{ Treatment } & \multirow{2}{*}{ Height } & \multirow{2}{*}{ Circumference } & \multirow{2}{*}{$\begin{array}{l}\text { Number of in- } \\
\text { ternodes }\end{array}$} & \multicolumn{6}{|c|}{ Fresh and dry weight (g)- } \\
\hline & & & & \multicolumn{2}{|c|}{ Shoots } & \multicolumn{2}{|c|}{ Leaves } & \multicolumn{2}{|c|}{ Roots } \\
\hline Control & $21.7 \mathrm{a}^{1}$ & $2.9 \mathrm{ab}$ & $6.2 \mathrm{a}$ & $14.2 \mathrm{ab}$ & $2.3 \mathrm{ab}$ & $13.8 \mathrm{ab}$ & $4.5 \mathrm{a}$ & 13.6 abc; & $1.1 \mathrm{abc}$ \\
\hline $\mathrm{M}^{2}$ & $10.2 \mathrm{c}$ & $2.0 \mathrm{~b}$ & $4.8 \mathrm{ab}$ & $5.9 \mathrm{c}$ & $0.9 \mathrm{~d}$ & $7.8 \mathrm{c}$ & $2.5 \mathrm{~cd}$ & $5.2 \mathrm{~d}$ & $0.4 \mathrm{f}$ \\
\hline $\mathrm{P}^{2}$ & $10.7 \mathrm{c}$ & $2.0 \mathrm{~b}$ & $5.2 \mathrm{ab}$ & $6.0 \mathrm{c}$ & $0.9 \mathrm{~d}$ & $7.2 \mathrm{c}$ & $2.0 \mathrm{~d}$ & $5.0 \mathrm{~d}$ & 0.8 cdef \\
\hline $\mathrm{H}^{2}$ & $14.6 \mathrm{bc}$ & $2.8 \mathrm{ab}$ & $5.2 \mathrm{ab}$ & $10.7 \mathrm{abc}$ & $1.6 \mathrm{abcd}$ & $12.2 \mathrm{abc}$ & $3.0 \mathrm{abcd}$ & 8.7 abcd; & 1.0 abcde \\
\hline$M+P$ & $15.4 \mathrm{bc}$ & $2.1 \mathrm{ab}$ & $4.2 \mathrm{~b}$ & $7.2 \mathrm{c}$ & $1.1 \mathrm{~cd}$ & $10.1 \mathrm{bc} ;$ & $2.9 \mathrm{bcd}$ & $8.1 \mathrm{ab}$ & 1.1 abcd \\
\hline$M+H$ & 13.9 bc & $2.6 \mathrm{ab}$ & $4.6 \mathrm{ab}$ & $9.1 \mathrm{bc} ;$ & 1.6 abcd & $11.2 \mathrm{abc} ;$ & $3.1 \mathrm{abcd}$ & 10.5 abcd; & $1.4 \mathrm{a}$ \\
\hline $\mathrm{P}+\mathrm{H}$ & $14.3 \mathrm{bc}$ & $2.8 \mathrm{ab}$ & $4.8 \mathrm{ab}$ & $10.5 \mathrm{abc}$ & $1.9 \mathrm{abc}$ & $12.4 \mathrm{abc}$ & $3.6 \mathrm{abc}$ & $14.3 \mathrm{ab}$ & $1.3 \mathrm{abc}$ \\
\hline $\mathrm{M}+\mathrm{P}+\mathrm{H}$ & $18.0 \mathrm{ab}$ & $3.0 \mathrm{a}$ & $5.6 \mathrm{ab}$ & $14.9 \mathrm{a} ;$ & $2.5 \mathrm{a}$ & $15.7 \mathrm{a} ;$ & $4.2 \mathrm{ab}$ & $15.1 \mathrm{a} ;$ & $1.4 \mathrm{a}$ \\
\hline
\end{tabular}

'Means with one or more letters in common do not differ significantly at the $5 \%$ probability level.

${ }^{2} \mathrm{M}-$ Meliodogyne incognita; $\mathrm{P}-$ Pratylenchus zeae; $\mathrm{H}-$ Pythium graminicola. 
nematodes, it can synthesize antagonistic substances (5), which can reduce the effect of $M$. incognita during giant cell formation. This would then limit gall size and even the normal physiological activities of the nematode. Therefore, the detrimental effects on the host are reduced and consequently the plant grows and develops better than when the two microorganisms act separately.

Pratylenchus zeae, when acting alone, reduces top growth, fresh weight of shoots, fresh and dry weight of leaves and fresh weight of roots. However, when the nematode combines with $P$. graminicola, only the height of primary shoots is affected and even then the effect is less than when the nematode is alone. The reduction of plant growth was much lower when both pathogens were together than when they were used separately (table 1 ). The same was true with respect to root necrosis (fig. 3). There was an apparent mutual inhibition or antagonism.

Although nematodes were not isolated from the soil, it is difficult to determine which organism is responsible for the reduction in height of primary shoots, because $P$. zeae is a migratory endoparasite, and normally its populations in the soil are low. However, it is evident that a reciprocal antibiosis exists between the two microorganisms, in which the fungus apparently develops better mechanisms of defense. The nematode does not seem to be able to colonize tissue already invaded by the fungus because of the presence of toxins and enzymes and/or decomposition products. On the other hand, the fungus, besides using for easy root penetration the ports of entry opened by $P$. zeae, can also colonize undigested tissue adjacent to the nematode, decomposing it and thus interfering with the normal migratory habits of the nematode. Likewise, the tissue already used as a substrate by the nematode could be of little nutritional value for the fungus, due to the sensitivity of the latter to metabolic by-products, which can act as a barrier for the advance of the hyphae. In this way the detrimental effects produced by $P$. zeae and $P$. graminicola are mutually reduced. The plant grows better when both microorganiasms act together than when they act separately.

The antibiosis is more pronounced when the three microorganisms act together. This is demonstrated by the fact that such values as stem circumference, weight of primary shoots, fresh weight of leaves and weight of roots of plants inoculated with the nematodes and the fungus simultaneously were higher than those of noninoculated plants. Moreover, the root necrosis index was low in these plants, although galls were smaller; the number was three times higher than those in roots infected with $M$. incognita alone (fig. 3). Apparently, in addition to antibiosis, the physiology of the plant is altered in a way that favors colonization by $M$. incognita, as evidenced by higher number of galls.

The results obtained in these greenhouse tests may not provide enough 
evidence to warrant conclusions as to what may happen under field conditions. However, the results may be indicative of what is happening in some localities where nematodes and fungi constitute serious obstacles to sugarcane culture.

\section{RESUMEN}

El estudio se realizó con el propósito de elucidar la participación de varios agentes biológicos en la etiología de la pudrición de la raíz de la caña de azúcar, de modo que dicha información pudiera sirvir como base para desarrollar métodos para el control de la enfermedad.

A raíces de plántulas de la cultivar PR 980, sembradas en invernadero, se les aplicaron los nematodos Meloidogyne incognita y Pratylenchus zeae y el hongo Pythium graminicola en tratamientos por separado y en combinaciones.

El experimento se cosechó a los 60 días tomádose datos de altura y circumferencia de los tallos; el peso de las raíces, tallos y hojas; cantidad de agallas; y niveles de necrosis.

La inoculación por separado con 1,600 y 1,200 especímenes, respectivamente de los nematodos Meloidogyne incognita y Pratylenchus zeae disminuyó significativamente el crecimiento, el peso de las cañas y las hojas y el peso húmedo de las raíces.

La combinación de ambos nematodos disminuyó en forma significativa el crecimiento, el peso de las cañas y el peso seco de las hojas, pero no tanto como cuando las plantas fueron inoculadas con ellos por separado. Este tratamiento disminuyó significativamente el número de entrenudos. Hubo cierto antagonismo entre las dos especies de nematodos que fue favorable para la planta, al aminorarse los daños ocasionados separadamente por cada especie.

El Pythium graminicola disminuyó significativamente el crecimiento. La combinación de cualquiera de las dos especies de nematodos con el hongo también mermó significativamente la altura de las cañas. Sin embargo, la combinación de los tres microorganismos no produjo mermas significativas, lo que sugiere la existencia de antagonismo entre el hongo y las dos especies de nematodos. Esto, aparentemente es beneficioso para la planta. El antagonismo fue más marcado cuando los tres patógenos actuaron conjuntamente. Bajo estas condiciones los nódulos, aunque más pequeños, eran más numerosos; la planta creció más, y el sistema radical se desarrolló mejor y con menos necrosis.

\section{LITERATURE CITED}

1. Anuario de Estadísticas Agrícolas de Puerto Rico, 1971-72, 1972. Departamento de Agricultura.

2. Apt, W. J. and Koike, H., 1962. Pathogenicity of Helicotylenchus nannus and its 
relation with Pythium graminicola on sugarcane in Hawaii, Phytopathology 52 (8): 798-802.

3. - and - -1962 . Influence of the stubby-root nematode on growth of sugarcane in Hawaii, Phytopathology 52 (9): 963-4.

4. - - and - 1962. Pathogenicity of Meloidogyne incognita acrita and its relation with Pythium graminicola on sugarcane in Hawaii, Phytopathology 52 (11): 1180-4.

5. Barton, R., 1960. Antagonism among some sugar-fungi, in: Parkinson, D. and J. S. Waid, Ed, The ecology of soil fungi: an international symposium, Liverpool Univ. Press, Liverpool, pp. 160-7.

6. Jenkins, W. R. and Taylor, D. P., 1967. Plant Nematology, Reinhold Publishing Corporation, New York, U.S.A., pp. 47-56.

7. Jensen, H. J., Martin, J. P., Wismer, C. A., and Koike, H., 1959. Nematodes associated with varietal yield decline of sugarcane in Hawaii, Plant Dis. Rep. 43 (2): 253-60.

8. Kahn, S. A., 1960. Studies of Pratylenchus zeae (Nematodatylenchida) on sugarcane in Louisiana, Diss. Abstr. 20: 2483.

9. Koike, H. and Román, J., 1970. Pathogenicity of Pratylenchus brachyurus and Pythium graminicola to sugarcane, Phytopathology 60 (11): 1562-5.

10. Liu, L. J., Adsuar, J., and Pérez, J. E., 1971. Disease of sugarcane and their control in Puerto Rico, J. Agri. Univ. P. R. 55 (2): 139-46.

11. Meléndez, P. L., 1970. The Pythium root-knot complex in flue-cured tobacco, Ph.D. Thesis, Dep. Plant Pathol. N. C. State Univ., Raleigh, N.C., pp. 80-1.

12. Rands, R. D. and Dopp, E., 1938. Pythium root rot of sugarcane, USDA Tech. Bull. 666.

13. Román, J., 1961. Pathogenicity of five isolates of root-knot nematodes (Meloidogyne spp.) to sugarcane roots, J. Agri. Univ. P. R. 45 (2): 55-84.

14. - 1967. Preliminary investigations of the nematodes associated with sugarcane in Puerto Rico, Proc. 12th Congr. Int. Soc. Sugarcane Tech. (Puerto Rico, 1965), Elsevier Publ. Co., New York N.Y., pp. 1401-2.

15. Thorne, G., 1961. Principles of Nematology, McGraw-Hill Book Company, Inc., New York, U.S.A., pp. 205-8, 312-35.

16. Wellman, F. L., 1972. Tropical American Plant Disease, Scarecrow Press, Inc., Metuchen, N.J., pp. 190-203.

17. Winchester, J. A., 1964. Nematodes as a factor in sugarcane varietal decline in Florida, Sugar J. 27 (1): 16-20. 